\title{
Synthesis of Spiro $\beta$-Lactams and Oxoindoles by Oxidative Dearomatization
}

Synthesis of Heterocycles

Key words

oxidative dearomatization

oxoindoles

$\beta$-lactams

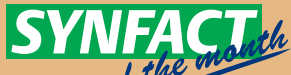<smiles>[2H]Nc1ccc(OC)cc1</smiles><smiles>CCOC(=O)CC(=O)Cl</smiles>
$\underset{\begin{array}{l}10 \text { examples } \\ 79-92 \% \text { yield }\end{array}}{\stackrel{\text { py, } \mathrm{CH}_{2} \mathrm{Cl}_{2}}{\longrightarrow}}$<smiles>[R]NC(=O)CC(=O)OCC</smiles><smiles>Cc1ccc(O)cc1</smiles>

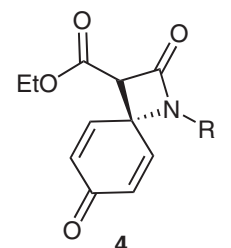

$\mathrm{R}=\mathrm{Bn}, 3-\mathrm{O}_{2} \mathrm{NBn}, 3,4,5-\mathrm{MeOBn}, 2-\mathrm{MeOBn}, 3-\mathrm{MeOBn}, 3,4-\mathrm{MeOBn}, 4-\mathrm{MeOBn}, i-\mathrm{Pr}, 3,4-\mathrm{MeOC}_{6} \mathrm{H}_{3} \mathrm{CH}_{2} \mathrm{CH}_{2}$, 3,4-methylenedioxybenzyl<smiles>CCOC(=O)C(P)C(=O)N(Cc1ccccc1)c1ccc(O)cc1</smiles>

1) IDB, $\mathrm{MeOH}$ 2) $\mathrm{DBU}, \mathrm{CH}_{2} \mathrm{Cl}_{2}$

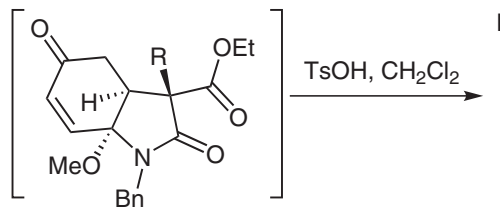

6

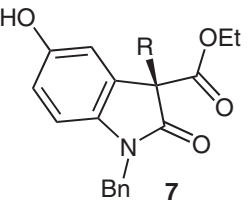

$\mathrm{R}=\mathrm{H}, n-\mathrm{Bu}, \mathrm{Bn}, \mathrm{Me}$, allyl

4 examples $81-89 \%$ yield
Significance: Reported is the synthesis of spiro $\beta$-lactams and oxoindoles by oxidative dearomatization of phenolic acetanilides. Following the lead of similar strategies developed by Kita for oxidative C-N coupling (Chem. Commun. 2007, 1224), the present group developed conditions for the conversion of phenolic amide $\mathbf{3}$ into spiro $\beta$-lactams 4 combining the $\mathrm{CuSO}_{4} \cdot 5 \mathrm{H}_{2} \mathrm{O}$, iodobenzene diacetate (IDB) and DMAP reagents. The reaction pathway may involve a radical coupling pathway involving oxidation reactions of IBD and $\mathrm{CuSO}_{4} \cdot 5 \mathrm{H}_{2} \mathrm{O}(\mathrm{H}$. Eickhoff, G. Jung, A. Rieker Tetrahedron 2001, 57, 353). However, an ionic pathway cannot be excluded. Using the phenolic amide $\mathbf{5}$ as starting material, similar conditions for obtaining oxoindoles $\mathbf{6}$ were developed which, however, were not isolated but converted into the corresponding oxoindoles $\mathbf{7}$ by treatment with $\mathrm{TsOH}$.
Comment: The $\beta$-lactam and oxoindole substructures are widely found in bioactive natural products and particularly in numerous pharmaceuticals such as penicillins and carbapenems (M. S. Butler Nat. Prod. Rep. 2005, 22, 162). An especially attractive feature of the present route is the use of common phenolic acetanilide starting materials. A significant disadvantage, however, is the need for $\mathrm{N}$-substituted precursors $\mathbf{3}$. 